\title{
Musculoskeletal complications in sickle cell anemia patients: a ten-year retrospective review of hospital-based records (1991-2000) in two Nigerian hospitals
}

\author{
Salamatu Umar Aliyu' ${ }^{1 *}$, Adamu A. Rufa' I' ${ }^{1}$, Ismaila A. Saidu', Abdurrahman M. Jajere ${ }^{2}$ \\ ${ }^{1}$ Department of Medical Rehabilitation (Physiotherapy), College of Medical Sciences, University of Maiduguri, Borno \\ State, Nigeria \\ ${ }^{2}$ Department of Physiotherapy, University of Maiduguri Teaching Hospital, Borno State, Nigeria
}

Received: 14 May 2015

Accepted: 21 June 2015

\section{*Correspondence:}

Dr. Salamatu Umar Aliyu,

E-mail: ptsalualiyu@yahoo.com

Copyright: $\odot$ the author(s), publisher and licensee Medip Academy. This is an open-access article distributed under the terms of the Creative Commons Attribution Non-Commercial License, which permits unrestricted non-commercial use, distribution, and reproduction in any medium, provided the original work is properly cited.

\section{ABSTRACT}

Background: Sickle Cell Anaemia (SCA) presents with various types of clinical manifestations that includes musculoskeletal manifestations that need the intervention of medical personnel including physiotherapy. The study aimed to determine the various musculoskeletal disorders associated with Sickle Cell Anaemia (SCA), types of treatments given including physiotherapy and the mortality rate in SCA patients admitted in two Nigerian hospitals.

Methods: It is a retrospective quantitative review of hospital-based records using patient's files and hospital registers. Ten years case notes of SCA patients were reviewed in two hospitals in Kano, North Western Nigeria. Information on age, gender, types of musculoskeletal disorders, types of treatments received including referrals for physiotherapy and number of deaths recorded within this period.

Results: Records shows a total of 248 patients admitted with SCA over this period. Results revealed 133 (53.6\%) males and 115 (46.4\%) females. Prevalence of musculoskeletal disorders was found to be 172 (54.1\%) out of the 318 SCA cases admitted. The commonest cause of hospital visitation was painful bone crisis (35.5\%). Followed by osteomyelitis and dactylitis accounting for $20(11.6 \%)$ of the musculoskeletal disorders respectively. Overwhelming majority $61.7 \%$ presenting with musculoskeletal disorders are between the age of 3 months and 10 years. The mortality rate was about $22 / 248(8.9 \%)$. Only $8.9 \%$ of these cases received physiotherapy.

Conclusions: Sickle cell disease affect a wider group of people than is commonly realised, screening for the disease is not universal and this together with a general lack of multi-disciplinary qualitative and clinical evidence-based treatment, leads to many inadequate management of individuals. Physiotherapy is one of the health care services that can be given following musculoskeletal presentations, yet it appropriateness in relation to the disease is rarely being addressed.

Keywords: Sickle cell anaemia, Musculoskeletal complications, Physiotherapy

\section{INTRODUCTION}

The term sickle cell disease is the prototype of hereditary hemoglobinopathies characterised by the production of structurally abnormal haemoglobin. ${ }^{1,2}$ These hemoglobinopathies include sickle cell anaemia ( $\mathrm{HbS})$, sickle cell hemoglobin $\mathrm{C}$ disease $(\mathrm{HbC})$ and sickle cell thalassaemia. ${ }^{3}$ Only the variant sickle cell $(\mathrm{HbS})$ with genotype SS and ( $\mathrm{HbC})$ sickle hemoglobin $\mathrm{C}$ are known to cause illness in Nigeria while sickle cell thalassaemia is of two types, the beta plus thalassaemia (Hbs $\beta+$ Thal.) and the alpha thalassaemia. The beta thalassaemia gene (usually $\beta+$ ) is very rare, but may occasionally interact 
with $\mathrm{HbS}$ to cause illness. In contrast $\alpha$ thalassaemia is common but is benign and asymptomatic.

HbSS is clinically the most important of all the genotypes that are encompassed in the broad definition of SCD and its manifestations are more severe. The clinical presentations of the diseases are often similar. Different SCD patients have different disease manifestations. ${ }^{4-8}$ Musculoskeletal manifestations constitute up to $80 \%$ of indications for presentation to hospital during their life time. ${ }^{9,10}$ Pain is the principal complaint either acute following skeletal or soft tissue infarction or chronic secondary to avascular necrosis of bone at various joints. $^{11}$

Generally recurrent vaso-occlussive episodes takes place in most organs of the body including sensitive ones such as the kidneys, lungs and the brain, resulting in chest syndromes, pneumococcal infections, strokes, priapism and renal complications which are clearly life threatening, ${ }^{12}$ other disorders associated with SCD mostly musculoskeletal are less life threatening but can drastically reduce quality of life overtime, these may include the hand and foot syndrome, vertebral collapse, painful bone crises, acute and chronic leg ulcers, acute and chronic osteomyelitis and back pain are just a few of the presenting problems ${ }^{12}$ in people living with the disease.

The disease can be seen in individuals in the equatorial Africa, Turkey, northern Greeks, eastern province of Saudi Arabia, Italy, parts of India and America. ${ }^{13}$ About 300000 infants are born with haemoglobinopathy, 200000 of whom are born in Africa $^{14}$ Whereas SCD occurs in 1 in 500 African-American births, it prevalence in countries such as Cameroon, Republic of Congo, Gabon Ghana and Nigeria is between $20-30 \%$ while in some parts of Uganda it is as high as $45 \% .{ }^{14}$ In Nigeria the current accurate figure of individuals with this disorder and associated problems is not known since the majority who were born to rural communities doesn't survive childhood. ${ }^{15}$ However, an estimate of $2-3 \%$ of the Nigerian population suffers from this disease and about $25 \%$ Nigerians are healthy carriers of the abnormal gene. ${ }^{15}$ The high incidence of SCD in Africa and other parts of the world is attributed to a hypothesis of "balanced polymorphism" in which the heterozygous $\mathrm{HbAS}$, carriers are protected against the severe effects of malaria in infancy and so have a survival advantage.

SCD causes a heavy burden on the society by the high morbidity and premature death associated with it. ${ }^{16}$ Sickle cell disease affect a wider group of people than is commonly realised, screening for the disease is not universal and this together with a general lack of multidisciplinary qualitative and clinically evidence-based treatment, leads to many inadequate management of individuals. Physiotherapy is one of the health care services that can be given following musculoskeletal presentations, yet it appropriateness in relation to the disease is rarely being addressed. Therefore there is lack of a holistic care towards these individuals even though few studies have elaborated on the role of physiotherapy in SCD individuals. ${ }^{3}$ In fact most studies on musculoskeletal presentations of SCA in Nigeria have focused on selected disease conditions. ${ }^{9,17,18}$ This study therefore determine the musculoskeletal complications, types of treatments given including physiotherapy and the mortality rate in SCA patients in two Nigerian hospitals.

\section{METHODS}

\section{Population and sampling procedure}

All admitted SCA cases between 1991 and 2000 were eligible for the study. The study was a retrospective quantitative review of hospital based records. It was carried-out in the medical records departments of Murtala Muhammad Specialist Hospital and Dala Orthopaedic Hospital both in Kano, Nigeria. Two hundred and forty eight cases of SCA were extracted from the hospital registers from 1991 to 2000 . Case notes $(n=248)$ of SCA patients who had attended either hospitals were scrutinized and reviewed for participants' medical history. Subjects included in this study were patients aged 3 months to $\geq 35$ years with haemoglobin genotype SS. Case notes containing incomplete data or unclear diagnosis were excluded from this study. Also other types of SCDs that are not SCA were not included in the study.

\section{Ethical consideration}

Ethical approval of the institutional review committee of Bayero University Kano was sought and obtained prior to the commencement of this study.

\section{Procedure}

SCD patients' case files covering a period of ten years from January 1991 - December 2000 were reviewed in two selected hospitals; National orthopaedic hospital, Dala and Murtala Muhammad Specialist Hospital Kano. The case notes of SCA patients treated and admitted at these hospitals were subjected to detailed scrutiny in the medical records section of each hospital. Ten years records were retrieved and reviewed. Cases of Musculoskeletal complications associated with SCA were extracted and recorded. The following data were collected from the SCA patients' case files; age of the patients, gender, types of disorders which patient was admitted to hospital from which cases of musculoskeletal disorders were extracted and recorded on data collection sheets, types of treatments received including referrals for physiotherapy and number of deaths recorded within this period.

Some of the case files listed on the registers where missing also some of the files has poor documentation or incomplete documentation in such instances there were excluded from the study. 


\section{Statistical analyses}

Descriptive statistics of percentages and frequency were used to describe the socio demographic characteristics (age, gender, cause of admission and mortality rate), various types of musculoskeletal complications admitted within this period, participants health seeking behaviours including physiotherapy referrals. Tables were used to present the results. The data were analysed using SPSS version 16.

\section{RESULTS}

Sociodemographic characteristics: A total of 248 SCA patients were admitted from 1991 to 2000. National orthopaedic Hospital Dala, Kano admitted 35 (14.1\%) SCA patients and Murtala Muhammad Hospital, Kano admitted 213(85.9\%) SCA patients within this period. Out of the total number of 248 SCA patients, 133(53.6\%) were males, while $115(46.4 \%)$ were females. The age of patients ranges from between 3 months - 35 years and above. The highest incidence of admission due to complications of SCA was recorded among the age group of 3 months to 5 years with $92(37.1 \%)$ recorded cases, followed by the age group of 6-10 years with $61(24.6 \%)$ recorded cases. The lowest number of admission was recorded among the age group of 35 years and above with $5(2.0 \%)$ recorded cases. The study observed 318 complications due to SCA within this period. 172 $(54.1 \%)$ were cases of musculoskeletal disorders while 146 (45.9\%) were other complications associated with SCA. A total number of 22 patients $(8.9 \%)$ were recorded dead and the remaining $226(91.1 \%)$ were discharged alive as of time of research (Table 1).

Table 1: Sociodemographic characteristics of the participants.

\begin{tabular}{|lll|}
\hline Sociodemographic variables & n & Percentage (\%) \\
\hline Age-group (years) & & \\
\hline $0.25-5$ & 92 & 37.1 \\
\hline $6-10$ & 61 & 24.6 \\
\hline $11-15$ & 29 & 11.7 \\
\hline $15-20$ & 20 & 8.1 \\
\hline $21-25$ & 24 & 9.7 \\
\hline $26-30$ & 10 & 4.0 \\
\hline $31-35$ & 7 & 2.8 \\
\hline$\geq 36$ & 5 & 2.0 \\
\hline Total & 248 & 100 \\
\hline Gender & & \\
\hline Male & 133 & 53.6 \\
\hline Female & 115 & 46.4 \\
\hline Total & 248 & 100 \\
\hline Cause of admission & & \\
\hline Musculoskeletal disorders & 172 & 54.1 \\
\hline Other disorders & 146 & 45.9 \\
\hline Total & 318 & 100 \\
\hline Mortality rate & 22 & 8.9 \\
\hline
\end{tabular}

Table 2 shows the musculoskeletal disorders seen among the SCA patients over ten years period. It shows that painful bone crisis is the most prevalent and cause of admission in these patients $(35.5 \%)$. Low back pain, osteomyelitis and hand and foot syndrome are the second most common disorders among these patients with 20 $(11.6 \%)$ each. The third most common cause of admission in this population was found to be (9.9\%) avascular necrosis. The study found the least musculoskeletal disorder presenting in this population to be rib infarction and vertebral collapse (1.2\% and $1.7 \%)$ respectively.

\section{Table 2: Musculoskeletal disorders among SCD} patients.

\begin{tabular}{|ll|l|}
\hline Musculoskeletal disorders & $\mathbf{n}$ & Percentage (\%) \\
\hline Avascular necrosis & 17 & 9.9 \\
\hline Painful bone crises & 61 & 35.5 \\
\hline Vertebral collapse & 3 & 1.7 \\
\hline Low back pain & 20 & 11.6 \\
\hline Chronic leg ulcers & 13 & 7.6 \\
\hline Osteomyelitis & 20 & 11.6 \\
\hline Hand and foot syndrome & 20 & 11.6 \\
\hline Rib infarction & 2 & 1.2 \\
\hline Septic arthritis & 10 & 5.8 \\
\hline Priapism & 6 & 3.5 \\
\hline Total & 172 & 100 \\
\hline
\end{tabular}

Table 3 shows the type of treatment received by these patients, out of a total number of 248 patients, all patients $(100 \%)$ receives various types of medical treatments and only $22(8.9 \%)$ receives physiotherapy treatment. Fourteen $(5.6 \%)$ also receives traditional treatment in addition to one or both of the stated treatments.

\section{Table 3: Types of treatments sought by the SCD} patients.

\begin{tabular}{|lll|}
\hline Type of treatment received & n & Percentages (\%) \\
\hline Overall No. of cases & 248 & 100 \\
\hline Medical management & 248 & 100 \\
\hline Physiotherapy referrals & 22 & 8.9 \\
\hline Traditional treatment & 14 & 5.6 \\
\hline
\end{tabular}

\section{DISCUSSION}

The study is a ten-year retrospective study that observes the frequency of musculoskeletal complications among patients with SCA in two hospitals in northern part of Nigeria. The study shows that various musculoskeletal diseases are reported with SCA, which is in line with. ${ }^{13}$ The prevalence of musculoskeletal disorders in this study is high $54.1 \%$. This prevalence is higher than that reported by Chinawa et al., ${ }^{19}(32.1 \%)$ and Balogun et al., ${ }^{20}(31.4 \%)$ in Nigeria.

The study reported painful bone crisis as the most prevalent musculoskeletal disorder representing 92 
$(35.5 \%)$ of the disorders, this agrees with, ${ }^{21}$ who stated that bone pain is the most common and rank as one of the most distressing disorder in SCA individuals and the most common reason for hospital visitation. ${ }^{22}$ It also agrees with the study of Chinawa et al., ${ }^{19}$ that reported lower limb and upper limb pain as the common cause of admitted cases of SCA in their study. In the same line ${ }^{23}$ reported pain crises including painful bone crisis to occur in all participants in their study as it is the most prevalent cause of health care consultation.

Osteomyelitis $20(11.6 \%)$ is the second most common musculoskeletal complication reported among the SCA patients in the current study. This prevalence is similar with the findings of ${ }^{19}(12.8 \%)$ but at variance with the prevalence of $(37.5 \%)$ and $(18 \%)$ reported by ${ }^{20,24}$ respectively. Salmonella has been thought to be responsible for osteomyelitis in children with SCA in more than $50 \%$ of cases ${ }^{25}$ and in over $70 \%$ of cases. ${ }^{26}$ The disease is thought to have a high tropism for patients with SCA. ${ }^{23}$ However, Zanoni et al., ${ }^{3}$ are of the opinion that in addition to the sensitivity of salmonella with SCA patients, the bad hygienic life conditions of the concerned population can explain an endemicity of salmonellosis in some regions especially in the developing countries, therefore buttressing the high prevalence of osteomyelitis among SCA patients in a developing country like Nigeria. The prevalence of septic arthritis in the current study is similar with previous reported prevalence of 6$15 \% .^{16,17,20,27}$

The study also reported hand and foot syndrome (dactylitis) and low back pain (11.6\%) respectively as one of the leading musculoskeletal disorders seen among these patients. This is in contrast with ${ }^{20}$ that reported a lower prevalence of $7.6 \%$ among their participants. However the study by ${ }^{19}$ did not report any incidence of dactylitis and low back pain in their five year review.

Avascular necrosis is one of the musculoskeletal complications of SCA among this population accounting for $9.9 \%$ of the total musculoskeletal complications in this study. Previous studies have reported avascular necrosis to occur in $3-21 \%$ of SCA patients. ${ }^{18-20}$ Sickle cell disease is the commonest cause off avascular necrosis in Nigeria. ${ }^{18}$

It was also shown that chronic leg ulcers carried about $13(7.6 \%)$ of the cases studied, this prevalence is lower than the $(10.7 \%)$ reported by ${ }^{20}$ and higher than prevalence reported by Chinawa et al., ${ }^{19}(1.3 \%)$. However the finding is in line with the study by ${ }^{30}$ Prasad et al. that reported ulcers to affect about $6 \%$ of Nigerian sicklers above the age of 12 years. The present study also reported $6(3.5 \%)$ of the males had priapism, which is in accordance with. ${ }^{15}$ however, some previous studies did not document the prevalence of priapism among SCA patients in Nigeria. ${ }^{19,20}$ These prevalence is low $(6 / 172)$ but the impending consequence is very tremendous.
The health seeking behaviour distinctively physiotherapy management is poor among the SCA patients. This might not be unrelated to poor referral system as regards to the sickle cell patients. Even though Physiotherapy has been seen to improve and efficiently treat musculoskeletal dysfunctions in SCA patients. ${ }^{3,31}$ According to ${ }^{32}$ majority of sickle cell patients managed with chemotherapy alone were seen as very unstable, hence, the recent development and treatment concepts advocate combination of several types of therapies other than chemotherapy alone, especially as regards joints pain and pain crisis. Therefore management of SCA requires holistic interdisciplinary evidence-based approaches. ${ }^{3}$ As SCA patients can benefit from physiotherapy there is a need for a functional referral system in these hospitals. There is also a need to develop further programme of physiotherapy care for individuals with SCA, consideration should be tailored toward Facilitation, delivery and exchange of information between those charged with managing the condition, i.e. the individual, physiotherapist and other members of the existing health care team. In addition provision of a functional assessment of the contexts in which the physiotherapist has to function need to be made very clear.

Fourteen cases $(5.6 \%)$ of the patients in additional to the conventional treatments (medical), also received traditional treatment in their respective community. Traditional medicine or treatments of SCA is a common practice in West Africa. In particular, the root of Fagara zanthoxyloides is widely used in West Africa both to prevent and to treat sickle crises. In vitro, the plant reverses sickling of red blood cells, ${ }^{33}$ but there has only been one very small published clinical trial. ${ }^{34}$ However, there are anecdotal reports of patients whose lives have been transformed by this treatment. If funding could be found for larger clinical trials to confirm the safety and efficacy of this medicine, this would be an important contribution to the care of sickle-cell patients both in Africa and in the rest of the world. ${ }^{35}$

The mortality rate of the patients as reported in this study is $(8.9 \%)$, Bacterial infections were found to be the leading cause of death among patients with SCA. ${ }^{28,29}$ although recent studies have indicated reduced mortality rate among SCA patients, because of the upward surge in life expectancy of sickle cell patients due to better understanding and correct management. ${ }^{36-38}$ In the same line recent studies have reported improvement in the life expectancy of SCA patients over the last century. ${ }^{37,38}$ Nevertheless, sickle cell disease causes a heavy burden on the society by the high morbidity and premature death associated with it. ${ }^{17}$ It was observed in the course of this study that no carrier state of the disease was admitted within the stated period of the study, which is in accordance with ${ }^{39}$ Oni et al., that most carrier state (those with the sickle trait) does not cause clinical pathology.

The study is not without limitations. Not all required information could be obtained from the hospital case files 
of the patients this leads to reduced sample size. Another limitation is that the study only covers two hospitals in Nigeria; therefore generalisation of findings should be used with caution. In addition other forms of SCDs were not included in the study therefore limiting findings to SCA patients merely.

The place of genetic counselling is obviously small in Nigeria. Young adults should seek for advice before marriage. Genetic counselling should be done at an age when the significance of counselling is understood but sexual associations and relationships not yet developed. Standardization of haemoglobin genotype determinations in our laboratories should be carried out for accurate and easy diagnosis. Haemoglobin electrophoresis should be made available to as many as required it.

\section{CONCLUSION}

The study concluded that various musculoskeletal complications associated with SCA patients exist as documented by previous studies. The most common complications reported is painful bone crises followed by osteomyelitis, low back pain and the hand and foot syndrome. Complication due to rib infarction reported lowest. There is also improvement in their life expectancy. Though there is need for improved and functional referral system as regard these patients.

\section{ACKNOWLEDGEMENTS}

The author sincerely thanks the participants of this study.

Funding: The study was self-funded

Conflict of interest: None declared

Ethical approval: The study was approved by the institutional review committee of Bayero University Kano

\section{REFERENCES}

1. Asani MR. Sickle cell disease. In: Stone JH, Blouin $\mathrm{M}$, eds. International Encyclopaedia of Rehabilitation, 2010. Available online at: http://cirrie.buffalo.edu/encylopedia/en/article/252.

2. Anyachukwu CC, Onuegbu GC, Eze SB. Evaluation of health profile of sickle-cell patients managed in university of Nigeria Teaching Hospital, Enugu South East, Nigeria. J Res Nurs Midwif (JRNM) 2014;3(5):94-9.

3. Zanoni CT, Galvao F, Cliquet Junior A, Saad STO. Pilot randomized controlled trial to evaluate the effect of aquatic and land physical therapy on musculoskeletal dysfunction of sickle cell disease patients. Rev Bras Hemoter. 2015;37(2):82-9.

4. Bainbridge R, Higgs DR, Maude GH, Serjeant GR. Clinical presentation of homozygous sickle cell disease. J Pediatr. 1985;106:881-5.

5. El-Hazmi MA, Bahakim HM, Al-Swailem AM, Warsy AS. The features of sickle cell disease in Saudi children. J Trop Pediatr. 1990;36:148-55.
6. Russo-Mancuso G, Romeo MA, Guardabasso V, Schiliro G. Survey of sickle cell disease in Italy. Haematologica. 1998;83:875-81.

7. Diop S, Mokono SO, Ndiaye M, Toure' Fall AO, Thiam D, Diakhate' L. La dre'panocytose homozygote apre' s l'a^ge de 20 ans: suivie d'une cohorte de 108 patients au CHU de Dakar. La revue de Me'decine Interne. 2003;24:711-5.

8. Inati A, Taher A, Bou Alawi W, Koussa S, Kaspar $\mathrm{H}$, Shbaklo $\mathrm{H}$, et al. B-Globin gene-cluster haplotypes and $\mathrm{HbF}$ levels are not the only modulators of sickle cell disease in Lebanon. Eur J Haematol. 2003;70:79-83.

9. Badhulkar SS, Pande K, Badhulkur S. The handfoot syndrome in sickle cell haemoglobinopathy. J Bone Joint Surg (Br). 1995;77B:310-2.

10. Omojola MC, Annobil S, Adzaku F, Addae SK, Mohammed S. Bone changes in SCA. East Afr Med J. 1993;70:154-8.

11. Ebong WW. Pathological fracture complicating long bone osteomyelitis in patients with SCD. J Paed Orthop. 1986;6:177-81.

12. Stewart M. Sickle cell disorders and physiotherapy. J CSP. 1997;83(3):333-9.

13. Serjeant GR. Sickle cell disease. In: Serjeant GR, eds. 2nd ed. A Book. London: Oxford University Press; 1992: 295.

14. World Health Organisation. Sickle cell anaemiareport by the secretariat 1-5. Fifty-Ninth World Health Assembly A59/9. Geneva: WHO; 2006.

15. Akinkugbe OO. Non-communicable disease in Nigeria. Ibadan, Nigeria: Spectrum Ltd.; 1992: 2325.

16. Moran MC. Osteonecrosis of the hip in sickle cell haemoglobinopathy. Am J Orthop. 1995;1:18-24.

17. Nade S. Acute septic arthritis in infancy and children. J Bone Joint Surg. 1983;65B:234-41.

18. Mijiyawa M. Musculoskeletal conditions in children attending two Togolese hospitals. Haematology. 1999;38:1010-3.

19. Chinawa JM, Chukwu BF, Ikefuna AN, Emodi IJ. Musculoskeletal complications among children with sickle cell admitted in University of Nigeria Teaching Hospital Ituku-Ozalla Enugu: a 58 month review. Ann Med Health Sci Res. 2013 OctDec;3(4):564-7.

20. Balogun RA, Obalum DC, Giwa SO, Adekoya-Cole TO, Ogo CN, Enweluzo GO. Spectrum of musculoskeletal disorders in sickle cell disease in Lagos, Nigeria. J Orthop Surg Res. 2010;5:2.

21. Sergeant GR. Sickle-cell disease. Lancet. 1997;350(9079)725-30.

22. Elander J. Sickle cell disease patients' experiences of hospital pain management. SCOOTER Project, 2013. Available at: http://www.sicklecellanaemia.org/OER/Resources/S COOTEROER72bPatient experiences.Pdf.

23. Ohara DG, Ruas G, Castro SS, Martins PRJ, Walsh IAP. Musculoskeletal pain, profile and quality of 
life of individuals with sickle cell disease. Braz J Phys Ther. 2012;16(5)431-8.

24. Ejindu VC, Hine AL, Mashayekhi M, Shorvon PJ, Misra RR. Musculoskeletal manifestations of sickle cell disease. Radiographics. 2007;27:1005-21.

25. Juliana AE, Muskiet FD. Salmonella osteomyelitis in a child with sickle cell disease. Ned Tijdschr Geneeskd. 2004;148(34):1695-8.

26. Onwubalili JK. Sickle cell disease and infection. J Infect. 1983;7(1):2-20.

27. Acurio MT, Friedman RJ. Hip arthroplasty in patients with sickle cell haemoglobinopathy. J Bone Joint Surg (Br). 1992;71B:367-71.

28. Leikin SL, Gallagher D, Kinney TR, Sloane D, Klug P, Rida W. Mortality in children and adolescents with sickle cell disease. Cooperative Study of Sickle Cell Disease. Pediatrics. 1989;84:500-8.

29. Diagne I, Soares GM, Gueye A, Diagnegueye NR, Fall L, N'Diaye O, et al. Infections in Senegalese children and adolescents with sickle-cell anemia: epidemiological aspects. Dakar Med. 2000;45:55-8.

30. Prasad A, Ali Khan M. A study exploring the prevalence, aetiology and possible significance of oedema in venous ulcers. Phlebology. 1990;5(8):181-7.

31. Neumayr LD, Aguilar C, Earls AN, Jergesen HE, Habercern CM, Kammen BF. Physical therapy alone compared with core decompression and physical therapy for femoral head osteonecrosis in SCD. Results of multicenter study at a mean of three years after treatment. J Bone Surg Am. 2006;88(12):2573-82.

32. Miller RE. Sickle cell anemia, 2013. Available at: http//:www.nemoursfoundation.com.

33. Sofowora EA, Isaac-Sodeye WA, Ogunkoya LO. Isolation and characterisation of an antisickling agent from Fagara zanthoxyloides. Lloydia. 1975;38(2):169-71.

34. Isaacs-Sodeye WA, Sofowora EA, Williams AO, Marquis VO, Adekunle AA, Andeson CO. Extract of Fagara zanthoxyloides root in sickle cell anaemia. Acta Haematol. 1975;53:158-64.

35. Willcox ML. Need for clinical trials on traditional medicine for sickle cell disease. BMJ Published Letters, 2005. Available at: http://www.bmj.com/.

36. Adelowo OO, Nwosu AO. Avascular necrosis not associated with haemoglobinopathy in Nigeria. Nigir Med Pract. 1999;37:15-7.

37. Sheth S, Licursi M, Bhatia M. Sickle cell disease: time for a closer look at treatment options? $\mathrm{Br} \mathrm{J}$ Haematol. 2013;162(4):455-64.

38. Osunkwo I. An update on the recent literature on sickle cell bone disease. Curr Opin Endocrinol Diabetes Obes. 2013;20(6):539-46.

39. Oni L. Sickle cell disease and the carer-client relationship. Nurs Times. 1998;94(26):64.

Cite this article as: Aliyu SU, Rufa'I AA, Saidu IA, Jajere AM. Musculoskeletal complications in sickle cell anemia patients: a ten-year retrospective review of hospital-based records (1991-2000) in two Nigerian hospitals. Int J Contemp Pediatr 2015;2:329-34. 